\title{
Spontaneous rupture of superficial temporal artery aneurysm presenting as hemifacial swelling
}

\author{
Dhiraj Joshi, ${ }^{1,2}$ Katherine Klimczak ${ }^{1}$
}

${ }^{1}$ Department of Clinical Radiology, North Bristol NHS Trust, Bristol, South Gloucestershire, UK ${ }^{2}$ Department of Clinical Radiology, University Hospitals Bristol NHS Foundation Trust, Bristol, UK

\section{Correspondence to} Dr Dhiraj Joshi,

dhiraj.joshi62@gmail.com
CrossMark

\footnotetext{
To cite: Joshi $D$

Klimczak K. BMJ Case Rep

Published online: [please

include Day Month Year]

doi:10.1136/bcr-2013-

202308
}

\section{DESCRIPTION}

A 60-year-old man presented with a day's history of sudden, spontaneous and severe swelling on the left side of the face and the neck. There was no history of trauma, surgery or radiotherapy. On examination, the patient was haemodynamically stable and there was discolouration and tenderness over the left side of the face. The patient was mildly anaemic. An unenhanced CT scan of the head demonstrated a large scalp haematoma in the left temporal region extending inferiorly (figure $1 \mathrm{~A})$. A comparison with MRI of the head (figure 1B) performed 2 years ago for epilepsy, revealed a $1.2 \mathrm{~cm}$ aneurysm of the superficial temporal artery (STA). This was initially missed by the radiologist and demonstrated in the hindsight only. A CT angiogram of the head and neck confirmed a $2 \mathrm{~cm}$ fusiform STA aneurysm (figure 2). There was no active contrast extravasation at the time of the angiogram; however, extensive haematoma in the surrounding tissue indicated a recent rupture. As the extensive haematoma required evacuation, surgical management was favoured over the possible endovascular and percutaneous treatment described previously. ${ }^{12}$ The aneurysm was excised and the two ends of the artery ligated. The haematoma was evacuated and the wound was closed primarily over a drain. The patient made an uneventful recovery. Histology

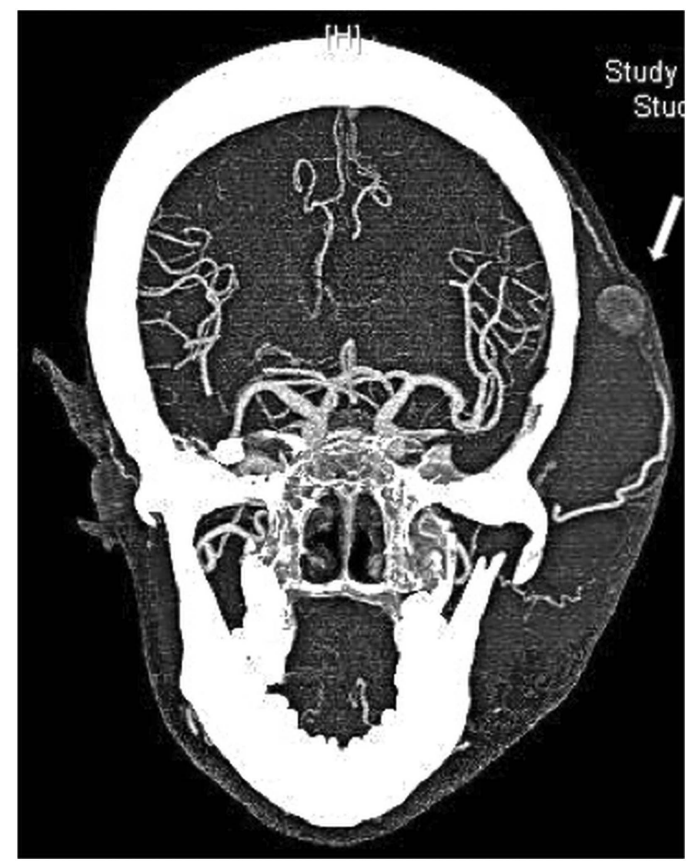

Figure $2 \mathrm{CT}$ angiogram. There is a fusiform aneurysmal dilation of the frontal branch of the left superficial temporal artery (arrow). The STA is a terminal branch of the external carotid artery (ECA). There is no active extravasation of contrast media.
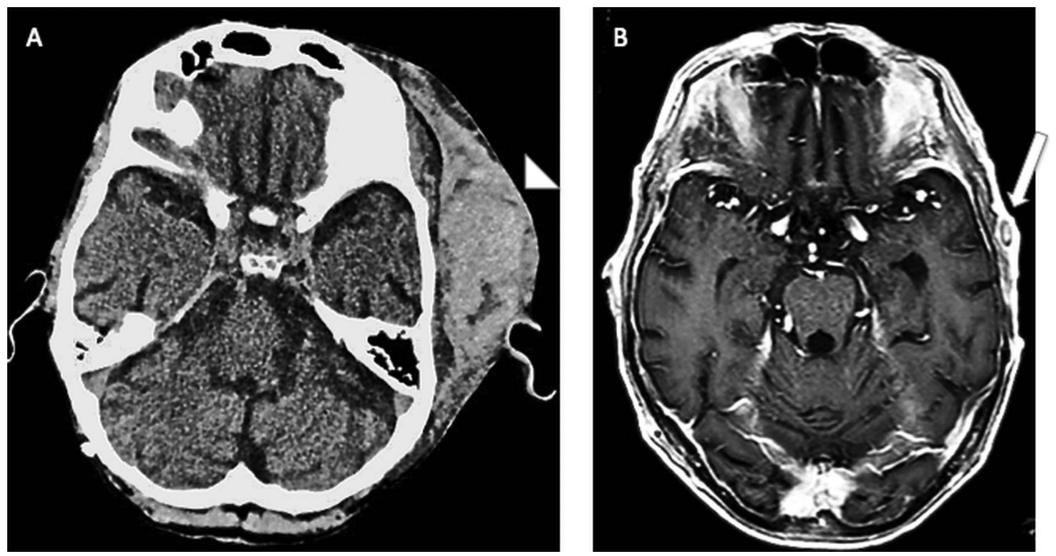

Figure 1 Comparison of the new and old cross-sectional studies of the head. (A) Axial CT scan of the head demonstrates a large scalp haematoma on the left side (arrowhead). (B) Axial T2 MRI of the head performed 2 years ago for epilepsy demonstrates an aneurysmal dilation of the left superficial temporal artery (arrow). This was an incidental finding which was initially missed. 
confirmed a true aneurysm of STA. There are several reports of STA aneurysms. ${ }^{3}$ However, rupture of an STA aneurysm has not been previously described and this is the first description of hemifacial swelling caused by a ruptured STA aneurysm.

\section{Learning points}

- An aneurysm of the superficial temporal artery (STA) is predisposed to rupture, and hence should be treated electively.

- It is essential to compare the current with the old diagnostic imaging. The STA aneurysm in this case may have remained unrecognised if the CT scan was not compared with MRI performed 2 years ago.

- Although rare, a ruptured aneurysm of the STA is an important cause for ipsilateral acute facial swelling. The more common causes include jugular vein obstruction, lymphoedema and inflammation.
Acknowledgements Dr Alex Mortimer, Neuroradiology Fellow, Frenchay Hospital, Bristol. Dr Shelly Renowden, Consultant Neuro Radiologist, Frenchay Hospital, Bristol. Neurosurgery Department, Frenchay Hospital, Bristol.

Contributors DJ wrote the case report. KK edited the text and wrote the quiz.

Competing interests None.

\section{Patient consent Obtained.}

Provenance and peer review Not commissioned; externally peer reviewed.

\section{REFERENCES}

1 Komiyama $\mathrm{M}$, Nakajima $\mathrm{H}$, Nishikawa $\mathrm{M}$, et al. Endovascular treatment of traumatic aneurysms of the superficial temporal artery. J Trauma 1997;43:545-8.

2 Yang HJ, Choi YH. Posttraumatic pseudoaneurysm in scalp treated by direct puncture embolization using $\mathrm{N}$-butyl-2-cyanoacrylate: a case report. Korean J Radio/2005;6:37-40.

3 Kaczynski J. Blunt head injury resulting in formation of the superficial temporal artery aneurysm. BMJ Case Rep 2012;2012.

Copyright 2014 BMJ Publishing Group. All rights reserved. For permission to reuse any of this content visit http://group.bmj.com/group/rights-licensing/permissions.

BMJ Case Report Fellows may re-use this article for personal use and teaching without any further permission.

Become a Fellow of BMJ Case Reports today and you can:

- Submit as many cases as you like

- Enjoy fast sympathetic peer review and rapid publication of accepted articles

- Access all the published articles

- Re-use any of the published material for personal use and teaching without further permission

For information on Institutional Fellowships contact consortiasales@bmjgroup.com

Visit casereports.bmj.com for more articles like this and to become a Fellow 